\title{
RMetS
}

Royal Meteorological Society

\section{Development of ice particles in convective clouds observed over the Black Forest mountains during COPS}

Yahui Huang, ${ }^{\text {a }}$ Alan M. Blyth, ${ }^{\mathrm{b}}$ Philip R. A. Brown, ${ }^{\mathrm{c} \dagger}$ Richard Cotton, ${ }^{\mathrm{c} \dagger}$ Jonathan Crosier, ${ }^{\mathrm{e}}$ Keith N. Bower, ${ }^{\mathrm{d}}$ Martin W. Gallagher, ${ }^{\mathrm{d}}$ Hazel Jones, ${ }^{\mathrm{d}}$ Alan M. Gadian, ${ }^{\mathrm{b}}$ Tom W. Choularton, ${ }^{\mathrm{d}}$ John Cardwell, ${ }^{\mathrm{d}}$ Hugh Coe, ${ }^{\mathrm{d}}$ Stephen D. Mobbs ${ }^{\mathrm{b}}$ and Martin Hagen ${ }^{\mathrm{f}}$

a Institute for Climate and Atmospheric Science, University of Leeds, UK

${ }^{\mathrm{b}}$ NCAS, School of Earth and Environment, University of Leeds, UK

${ }^{\mathrm{c}}$ Met Office, Exeter, UK

${ }^{\mathrm{d}}$ School of Earth, Atmospheric and Environmental Sciences, University of Manchester, UK

${ }^{\mathrm{e}}$ NCAS, School of Earth, Atmospheric and Environmental Sciences, University of Manchester, UK

${ }^{\mathrm{f}}$ Institut für Physik der Atmosphäre, Deutsches Zentrum für Luft- und Raumfahrt, Oberpfaffenhofen, Germany

${ }^{\star}$ Correspondence to: Y. Huang, School of Earth and Environment, University of Leeds, LS2 9JT, UK.

E-mail: y.huang@see.leeds.ac.uk

${ }^{\dagger}$ The contributions of P. R. A. Brown and R. Cotton were prepared in the course of their employment at the Met Office, UK, and are published with the permission of the Controller of HMSO and the Queen's Printer for Scotland.

A combination of modelling studies and ground-based and aircraft measurements is used to examine the development of ice particles in convective clouds observed over the Black Forest mountains during the Convective and Orographically-induced Precipitation Study (COPS). High concentrations of relatively small ice particles were observed in the weaker northern cell that developed on convergence lines over the mountains in the much-studied 15 July 2007 case. The conditions in the cloud were not conducive for the Hallett-Mossop process. Instead, the explanation for such high concentrations of ice is likely associated with the type of ice nuclei ingested into the cloud. Biological nuclei, oxidised organic aerosol particles in the polluted air vented from the Murg valley into the cloud base, and desert dust are all possible candidates. A model sensitivity test with biological nuclei produced similar concentrations of ice particles to the observations. In contrast, the high concentration of ice particles measured in clouds that advected over the Black Forest mountains on 11 July 2007 were likely due to the Hallett-Mossop process. The deep convective cell at the southern end of the COPS domain on 15 July 2007 developed in less polluted air than the shallower northern cloud. A model sensitivity test with lower aerosol loading produced a more vigorous cloud with a higher top, more precipitation, and greater reflectivity, more similar to the radar observations. The results suggest that aerosol particles vented out of the valleys could have a significant impact on orographically induced precipitation. Copyright (c) 2011 Royal Meteorological Society and Crown copyright, the Met Office

Received 2 March 2010; Revised 5 October 2010; Accepted 26 November 2010; Published online in Wiley Online Library 11 February 2011

Citation: Huang Y, Blyth AM, Brown PRA, Cotton R, Crosier J, Bower KN, Gallagher MW, Jones H, Gadian AM, Choularton TW, Cardwell J, Coe H, Mobbs SD, Hagen M. 2011. Development of ice particles in convective clouds observed over the Black Forest mountains during COPS. Q. J. R. Meteorol. Soc. 137: 275-286. DOI:10.1002/qj.749

1. Introduction

Clouds and precipitation play a critical role in the global hydrological cycle, which is a major factor in climate change. Convective clouds are the cause of severe weather such as flash floods which directly affect the quality of human lives.
The accuracy of forecasts of flash floods, such as occurred at Boscastle in the UK in 2004 (Golding et al., 2005), depends, in part, on our understanding of the microphysics of the clouds, including the formation and development of ice particles and precipitation. However, there are still many questions about how ice particles are initiated, and how high 
concentrations of ice particles are produced in clouds, and therefore about the production of precipitation.

There have been many reports of ice particle concentrations that are much higher than typical concentrations of ice nuclei (e.g. Mossop et al., 1972; Hobbs and Rangno, 1985; Harris-Hobbs and Cooper, 1987; Blyth and Latham, 1993; Bower et al., 1996). Among the suggested secondary ice production processes, the Hallett-Mossop (HM) process of splintering during riming (Hallett and Mossop, 1974) has received the most attention and is the most quantified. Although experiments (Hallett and Mossop, 1974; Mossop and Hallett, 1974; Mossop, 1978, 1985; Saunders and Hosseini, 2001) have shown strict conditions for the operation of the HM process, there is considerable evidence that this process operates in cumulus clouds in many parts of the world (e.g. Harris-Hobbs and Cooper, 1987; Blyth and Latham, 1993; Hogan et al., 2002; Huang et al., 2008).

Considerable effort has been made recently on identifying ice nuclei either in laboratory experiments, such as the one conducted at the Aerosol Interactions and Dynamics in the Atmosphere (AIDA) cloud chamber (Möhler et al., 2006; Field et al., 2006), or in the observations of real clouds. For example, Pratt et al. (2009) used an aircraft singleparticle Aerosol Mass Spectrometer to directly measure the chemistry of individual cloud ice-crystal residues over Wyoming. They found that biological particles and mineral dust accounted for about $33 \%$ and $50 \%$ of the residues, respectively. Choularton et al. (2008) also pointed out the likely importance of the chemical composition of aerosol particles in ice nucleation. They observed rapid transitions between highly glaciated regions and regions consisting of supercooled water, and suggested that the transition was caused by ice nucleation initiated by oxidised organic aerosol coated with sulphate in the more polluted regions of the cloud. The highly oxidised aerosols first acted as cloud condensation nuclei (CCN) and then as ice nuclei (IN).

In numerical models, most of the ice nucleation schemes do not resolve the different characteristics of IN in terms of their ice nucleating efficiencies. They may work for a 'mean' ice nucleus, but may not for a specific situation, such as the one Choularton et al. (2008) observed. Diehl and Wurzler (2004) and Diehl et al. (2006) developed a new approach of immersion freezing which considered the ice nucleation characteristics of different insoluble particles. Levin et al. (2005) also included the chemical composition of aerosol particles in their simulations of the events during a dust storm.

The purpose of this article is to address the question of ice particle development in the clouds that formed on two days during the Convective and Orographicallyinduced Precipitation Study (COPS) held in the Black Forest mountains in southwest Germany and the Vosges mountains in eastern France during the summer of 2007. Ground-based measurements of aerosol particles and aircraft measurements of aerosol and cloud particles are used in conjunction with an axisymmetric cloud model with sophisticated microphysics: the Model of Aerosols and Chemistry in Convective Clouds, MAC3. In addition, we examine the role of aerosols in the development of the much-studied cloud observed on 15 July 2007 (IOP8b; Richard et al., 2011). The details of the field experiment and model are discussed in sections 2 and 3, respectively. In section 4 we show in situ and ground-based observations of aerosol particles and in situ cloud measurements gathered on 15 July. We then show the results of MAC3 model runs performed using the input aerosol data with the standard and modified IN. We finally present a model run with a low concentration of aerosols. In section 5, we discuss a different case (11 July 2007) where high concentrations of ice were observed, which MAC3 model results suggest are due to the HM process. The conclusions are given in section 6 .

All altitudes are given above mean sea level (amsl), and times in Coordinated Universal Time (UTC), which is $2 \mathrm{~h}$ behind local time.

\section{Details of experiment}

COPS was conducted from 1 June to 31 August 2007 in the Black Forest mountains region in southwestern Germany and the Vosges mountains in eastern France to understand the physical processes responsible for the initiation and development of precipitating convection (Wulfmeyer et al., 2008, 2011). A map of the Black Forest mountains showing the main geographical features discussed in the article is shown in Figure 1. The data discussed in this article were gathered with the UK Facility for Airborne Atmospheric Measurements (FAAM) BAE-146 research aircraft and also with instruments in the aerosol container located on Hornisgrinde at supersite $\mathrm{H}$. We also show data from the polarimetric C-band Doppler research radar POLDIRAD (Schroth et al., 1988) which was deployed in the foothills of the Vosges mountains about $20 \mathrm{~km}$ northwest of Strasbourg, and mention data gathered with the Institute for Meteorology and Climate Research (IMK) radar located at Karlsruhe. The aircraft made penetrations near the tops of convective clouds as they ascended. Legs were also made below the cloud base to investigate the properties of aerosol particles. Many ground-based facilities were deployed at five supersites, such as radars, lidars, radiosondes, and aerosol instruments (Wulfmeyer et al., 2008). Data are presented from the Aerodyne Time of Flight Aerosol Mass Spectrometer (ToF-AMS; Drewnick et al., 2005) and the Grimm Optical Particle Counter (OPC, model 1.108) which were deployed in the aerosol container behind a $4 \mu \mathrm{m}$ impactor. The size range of the ToF-AMS is about 70 to $700 \mathrm{~nm}$, while that of the OPC is 0.3 to $20 \mu \mathrm{m}$.

Aerosol size distributions and concentration of aerosols were measured by a PMS Passive Cavity Aerosol Spectrometer Probe (PCASP; Kin and Boatman, 1990; Strapp et al., 1992) and a Condensation Particle Counter (CPC, TSI model 3025; Gilmore, 2002). In situ microphysical measurements were made with the Johnson-Williams probe for liquid water content (LWC), the 2DC (cloud) and 2DP (precipitation) probes (Knollenberg, 1970; Jensen and Granek, 2002; Korolev, 2007), the Cloud Particle Imager (CPI; Lawson et al., 2001; Connolly et al., 2007) and the Small Ice Detector (SID-2; Cotton et al., 2010), on board the FAAM BAE-146 aircraft. The Fast Forward Scattering Spectrometer Probe had technical problems and so was not used in this study. The concentrations of ice particles were derived from the SID-2, 2DC and 2DP probes. The nominal size ranges of SID-2 and the CPI are $2-280 \mu \mathrm{m}$ and $10-2000 \mu \mathrm{m}$, respectively, while for the 2DC and 2DP are 25-800 $\mu \mathrm{m}$ and 200-6400 $\mu \mathrm{m}$, respectively. Since there are known problems with the 2DC instrument for sizes smaller than about $100 \mu \mathrm{m}$ diameter, only particles with diameters greater than $150 \mu \mathrm{m}$ were used in the analysis. Concentrations were calculated 
after rejection of zero-area images, splashes, streakers, and hollow images.

Cotton et al. (2010) found that SID-2 cannot discriminate the phase of all particles correctly where there are high concentrations of cloud droplets. In the probe configuration that was flown in this project, the small trigger volume is surrounded by an extended sensing volume. When the droplet concentration exceeds a few tens of $\mathrm{cm}^{-3}$, the coincidence of particles in this sensing volume with another particle in the trigger volume becomes significant. The detector records a signal which is the sum of scattered intensity of the coincident particles. This leads to a nonuniform azimuthal detector element response and the skewing of the particle size distribution toward larger particle sizes. However, detected particle sizes above $50 \mu \mathrm{m}$ are increasingly unlikely to be from coincidence events. Hence, we take the concentration of non-spherical particles above this threshold as being a more plausible upper limit on the ice crystal concentration.

Wind measurements were calculated from the inertial navigation system and turbulence probe on the radome in a manner described by Lenschow and Spyers-Duran (1987). Errors in horizontal winds were experienced during turns, as expected, but our interests were only in straight segments of flight through cloud. Vertical wind is thought to have an absolute accuracy within $\pm 0.5 \mathrm{~m} \mathrm{~s}^{-1}$ at best, although the resolution is better than $0.05 \mathrm{~m} \mathrm{~s}^{-1}$. The ports on the turbulence probe occasionally iced up in supercooled cloud, but this did not occur during the most of the penetrations discussed in this article. An estimation of the altitude of cloud top was made using the on-board forward-looking video camera. Most penetrations were made within a few hundred metres of cloud top.

\section{Description of model}

MAC3 was employed to simulate the clouds. MAC3 is a 2D axisymmetric non-hydrostatic bin-resolved two-moment cloud model that has been developed and used for many years (Reisin et al., 1996; Yin et al., 2000, 2005; Cui and Carslaw, 2006; Huang et al., 2008). There is a detailed treatment of most major microphysics processes, including nucleation, growth, break-up and sedimentation for both liquid drops and ice phase particles (ice crystal, graupel, and snow). MAC3 includes detailed calculations of the splinter production during riming (HM process) which was quantitatively described by Hallett and Mossop (1974) and Mossop (1978). The riming rate is directly calculated in the model by solving the stochastic collection equation for drops and ice phase particles with size distributions that are explicitly predicted. The model domain used here and later was $12 \mathrm{~km}$ in the vertical and $6 \mathrm{~km}$ in the radial direction with a grid size of $300 \mathrm{~m}$ and $150 \mathrm{~m}$, respectively. The observations of the sub-cloud aerosol particle distribution from the PCASP were used for the aerosol background conditions (Huang et al., 2008). The aerosol size distribution below $100 \mathrm{~nm}$ was assumed to be identical to that from Gras (1995).

\section{Case 1: 15 July 2007}

The COPS region was on the western edge of a highpressure ridge over eastern Europe (Kottmeier et al., 2008; Kalthoff et al., 2009) which resulted in warm, dry and sunny conditions over the Black Forest mountains. The ridge was present from 14 to 16 July. Two precipitating convective clouds developed to the east of the Black Forest crest (Aoshima et al., 2008). As pointed out by Kalthoff et al. (2009) and Behrendt (2011), the convection was triggered by a passing convergence zone, which was intensified by convergence lines formed by the thermally induced mountain and valley flows. The cloud base height was about $2.9 \mathrm{~km}$ amsl in the north; it was not measured in the south. The southern cloud developed into a mature, deep thunderstorm with a cloud top of about $12 \mathrm{~km}$ amsl. In contrast, the northern cloud was comparatively shallow with a top of only about $6 \mathrm{~km}$ amsl and with weak precipitation. The BAE-146 aircraft penetrated the northern cloud near its top.

\subsection{Observations of aerosols}

Two racetrack runs were made heading south over the Rhine valley at $0.9 \mathrm{~km}$ amsl and returning north over the mountains at the western edge of the Black Forest at $1.7 \mathrm{~km}$ amsl. Figure 1 shows the track of the aircraft in the first northern leg from 1335 to 1346 UTC. The location of the northern and southern clouds at 1330 UTC determined from visible satellite imagery is indicated in the figure. The convergence line and cloud passed over the Murg valley from about 1300 to 1400 UTC. The reflectivity of the cloud at the time it produced the first echo (1430 UTC) measured by the Polarization diversity Doppler Radar (POLDIRAD) shows the progression of the cloud. The magnitude of the vertical air velocity is shown along the track and indicates that there was a strong updraught on the west side of the Murg valley. Figure 2 shows the aircraft measurements of vertical velocity and concentration of aerosols from the CPC and PCASP along the flight track (Figure 1). The strong updraught occurred when the aircraft flew over the western edge of the Murg valley, with maximum speed greater than $5 \mathrm{~m} \mathrm{~s}^{-1}$ at $\left(8.34^{\circ} \mathrm{E}, 48.60^{\circ} \mathrm{N}\right)$ and a simultaneous rapid rise in the concentration of aerosols measured by the CPC (maximum $7000 \mathrm{~cm}^{-3}$ ) and the PCASP (maximum $1500 \mathrm{~cm}^{-3}$ ). There was also a significant increase in relative humidity $(\mathrm{RH})$. The backscattering signal from the Leibniz Institute for Tropospheric Research multiwavelength Raman lidar BERTHA (Backscatter Extinction lidar Ratio Temperature Humidity profiling Apparatus) located in the Murg valley was relatively strong up to about $3 \mathrm{~km}$ amsl from about 1200 to 1400 UTC. The updraught over the Murg valley was much stronger than that over the Kinzig valley, most likely because thermally induced convergence lines were stronger over the Murg valley and also because the aircraft encountered the passing convergence zone while flying over the Murg valley (Kalthoff et al., 2009). The proximity of the venting, strengthened by the convergence zone, which triggered the northern convective cells, combined with the high concentration of aerosols measured by the aircraft instruments and the high backscattering signal, suggests that a high concentration of aerosols was ingested into the cloud.

An overview of the composition of aerosols from the ToF-AMS at supersite $\mathrm{H}$ is shown in Figure 3. We can see that the mass concentration of organic material measured by the ToF-AMS was far higher than that of the other aerosol component species on 15 July and there was a buildup of the mass of organics from 14 to 16 July. There is 


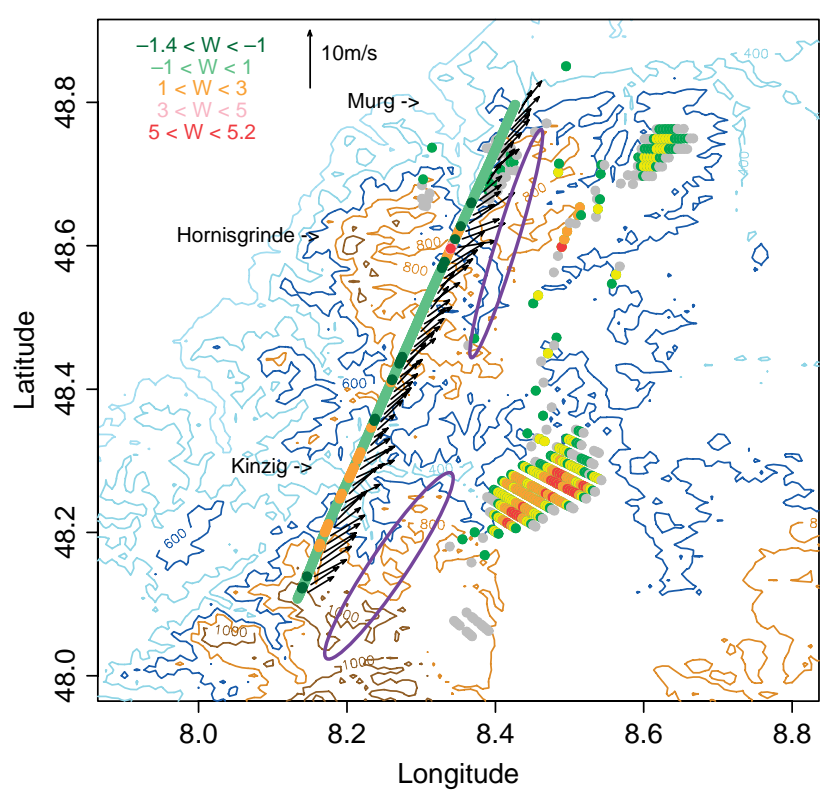

Figure 1. Flight track of aircraft heading north over the mountains from 1335 to 1346 UTC on 15 July 2007. The magnitude of the updraught speed is indicated by the colour scale. Wind vectors show the horizontal wind direction and speed. The two ellipses show the location of the clouds as determined by the satellite images at 1330 UTC, and the coloured dots indicate the reflectivity (dBZ) measured by POLDIRAD at 1430 UTC. The colour scale for the reflectivity is -5-10, 10-20, 20-30, 30-40, 40-50, and 50-60 dBZ in grey, green, yellow, orange, red, and dark red, respectively. The coloured lines are the elevation with contours at 200,400,600,800, and $1000 \mathrm{~m}$. The location of POLDIRAD is $\left(7.61^{\circ} \mathrm{E}, 48.74^{\circ} \mathrm{N}\right)$. The IMK radar was located at Karlsruhe $\left(8.36^{\circ} \mathrm{E}, 49.01^{\circ} \mathrm{N}\right)$. Note that one tenth of a degree of longitude is $7.4 \mathrm{~km}$ and $7.3 \mathrm{~km}$ at latitudes 48 and $49^{\circ} \mathrm{N}$, respectively.

also some evidence of a peak in the middle of the day on 15 July. As already mentioned, there was a high pressure ridge situated over Europe on 14-16 July with high solar radiation resulting in high temperatures. Therefore there was likely to be increased emissions of biogenic volatile organic compounds (VOCs) oxidation products from the forest (Mentel et al., 2009).

Measurements of particle growth factors were obtained at supersite $\mathrm{H}$ using a Hygroscopicity Tandem Differential Mobility Analyser (HTDMA) and are discussed by Irwin et al. (2010). Hygroscopic growth factor is defined as the ratio of the particle diameter at a target $\mathrm{RH}$ ( $85 \%$ in this case) to the dry particle diameter (obtained at $\mathrm{RH}<15 \%$ ). Data from the HTDMA show narrow mono-modal growth factor distributions, which is suggestive of an internal mixture of the inorganic and organic particulate components (Irwin et al., 2010). This suggest that the organic material is secondary in nature and has condensed onto pre-existing aerosol. This could possibly be a result of the photooxidation of biogenic gas-phase material, but this cannot be confirmed from the measurements. The fact that there is little black carbon, sulphate and nitrate, and the site is far from local pollution sources, supports the notion of organics being biogenically produced. At the same time as the high organic concentrations, significant amount of coarse-mode material was measured by the Grimm OPC (despite the use of the impactor on the inlet). The composition of this coarse-mode material is unknown, but could be associated with primary biogenic emissions, such as leaf litter. However, the possibility of the presence of dust cannot be ruled out as there were no measurements of coarse-mode composition.
There is evidence suggesting that various biogenic particles are IN (e.g. Szyrmer and Zawadzki, 1997; Levin and Cotton, 2009). As early as 1966, measurements made by Soulage (1966) indicated that pine forests raise the icenucleating activity. In addition, recent work carried out at the AIDA chamber (Möhler et al., 2005) has shown that a sulphate coating can considerably increase the effectiveness of the immersion nuclei, which can be further enhanced by the presence of oxidised organic material. Choularton et al. (2008) pointed out that a possible source of the ice particles observed at Jungfraujoch is immersion freezing by organic/carbon particles that were carried up in plumes of polluted air. Thus, it is possible that the oxidised organics ingested into the northern cell on 15 July 2007 first acted as effective CCN and then IN. There is also some suggestion that there was dust present. In the following section, MAC3 will be used to simulate the 15 July cloud to test the effect of aerosols on the microphysics of the clouds.

\subsection{Cloud observations}

According to the IMK radar observations (not shown) the reflectivity of the northern convective cell had reached a maximum value (35-40 dBZ) and precipitation (with reflectivity of $30 \mathrm{dBZ}$ ) had reached the ground before the time of the first aircraft penetration (1445 UTC).

The reflectivity had just begun to decrease when the aircraft made the first penetration. The radar reflectivity did not increase again. Evidently, the aircraft penetrated a new cell which did not produce precipitation. The observations of vertical wind, liquid water content (LWC) and concentration of ice particles with diameter $d>50 \mu \mathrm{m}$ from the SID-2 instrument during the first three penetrations are shown in Figure 4. The updraught measured in the cloud was strong with maximum values of about 10 and $11.5 \mathrm{~m} \mathrm{~s}^{-1}$ in the first and second penetrations, at 1445 UTC and 1457 UTC, (Figures 4(a) and (b)), respectively. The aircraft followed the cloud top as it ascended. The maximum values of LWC in both penetrations was $1.4 \mathrm{~g} \mathrm{~m}^{-3}$, despite the strong updraught. It is clear that considerable entrainment had occurred since the adiabatic values are about $4 \mathrm{~g} \mathrm{~m}^{-3}$. The relatively low values of LWC in such strong updraughts is most likely because of the relatively small size of the turrets (about $1 \mathrm{~km}$ ), allowing the cores of the thermals to be eroded (Blyth et al., 2005). There is an average decrease in both the values of vertical wind and LWC towards the downshear side of the cloud evident in Figure 4(b) and there is a strong downdraught of about $-7 \mathrm{~m} \mathrm{~s}^{-1}$. This greater dilution downshear has often been observed in clouds and, indeed, Hobbs and Rangno (1985) showed that ice particles developed in downshear regions. The average temperatures measured in the first two runs were approximately -4 and $-7^{\circ} \mathrm{C}$. There is evidence of ice particles in the downdraughts in both of these penetrations. Blyth and Latham (1993) observed the first ice particles in the downdraughts of New Mexico clouds. Figures 4(a) and (b) show the maximum concentrations of ice particles larger than $50 \mu \mathrm{m}$ of about 60 and 150 litre $^{-1}$ in the first and second penetrations, respectively. There is a distinct absence of these larger ice particles in the updraughts in both penetrations.

The cloud continued to ascend, but had obviously begun to decay by the time of the next penetration at 1508 UTC (Figure $4(\mathrm{c})$ ), which was at a temperature of $-9^{\circ} \mathrm{C}$. There was a strong downdraught of more than $-10 \mathrm{~m} \mathrm{~s}^{-1}$ resulting 


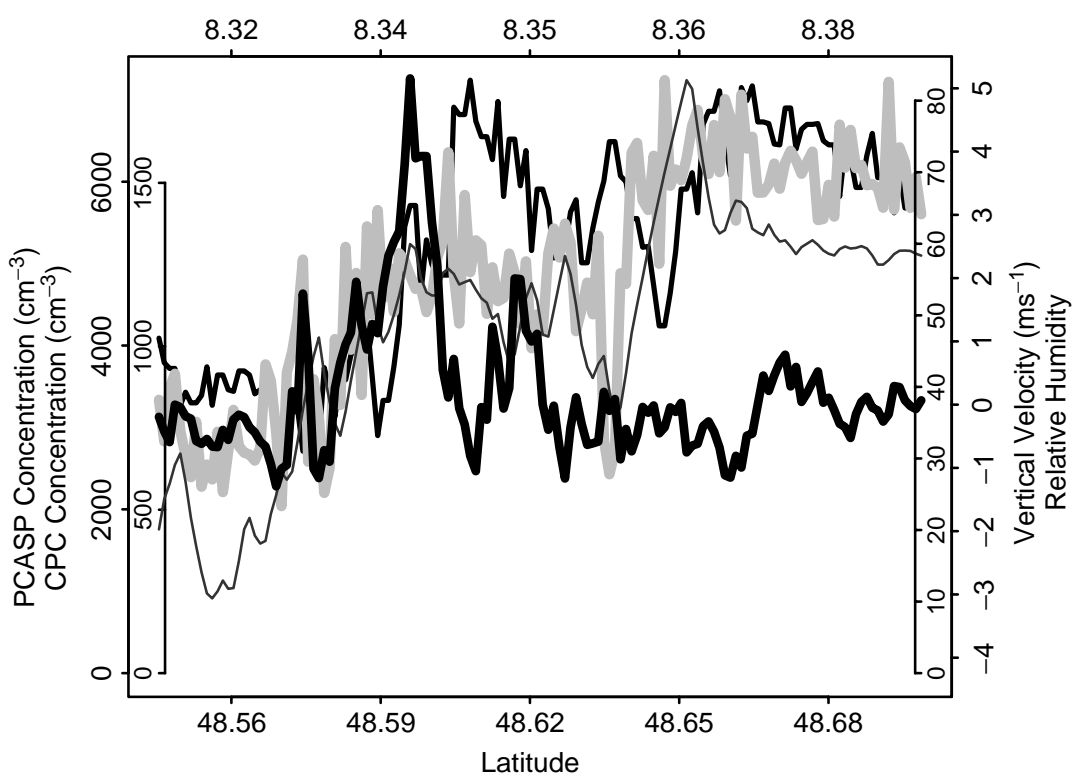

Figure 2. Measurements of vertical velocity (bold black line), concentrations of aerosols from the CPC (thin black line) and PCASP (bold grey line), and relative humidity (thin grey line) along the flight track shown in Figure 1 when the aircraft flew over the Murg valley from southwest to northeast on 15 July 2007. The figures along the top axis are longitudes along the flight track, corresponding to the latitudes shown on the bottom axis.

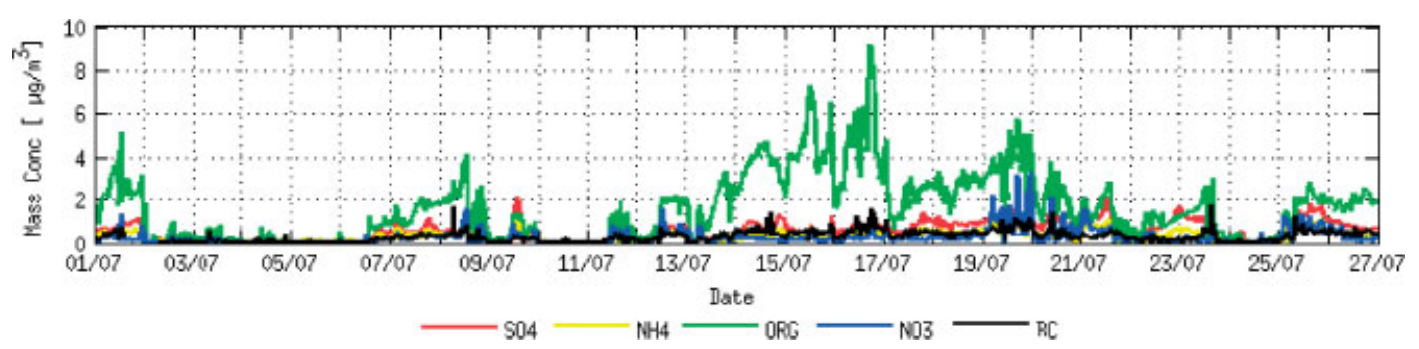

Figure 3. Composition overview from ToF-AMS at supersite H during July 2007.

from entrainment of the dry air causing strong evaporative cooling. The maximum concentration of the ice particles $(d>50 \mu \mathrm{m})$ detected by the SID-2 probe had increased to about 300 litre $^{-1}$ in the strong downdraught. Although the majority of particles measured by the CPI were too small $(d<40 \mu \mathrm{m})$ to distinguish between water and ice particles, the instrument did detect a few ice particles larger than $400 \mu \mathrm{m}$ in the downdraught. The maximum concentration of particles detected by the $2 \mathrm{DP}$ was 0.9 litre $^{-1}$ in the downdraught. The aircraft penetrated close to the top of the cloud in the next penetration at $T=-10^{\circ} \mathrm{C}$. Downdraughts were measured across most of the cloud (not shown) and there were lower concentrations of the ice particles $(d>50 \mu \mathrm{m})$. However, one $200 \mathrm{~m}$ wide updraught $\left(w_{\max } \approx 6 \mathrm{~m} \mathrm{~s}^{-1}\right)$ was observed with no larger ice particles detected by the SID-2 instrument.

Thus the evidence from SID-2 suggests that there was a high concentration of ice particles (total concentration, $N_{\mathrm{i}}>300$ litre $^{-1}$ ) measured in the downdraught of the cloud whose top reached no higher than $T \approx-12^{\circ} \mathrm{C}$.

\subsection{MAC3 simulations}

A modified sounding from Achern at 1300 UTC on 15 July 2007 was used for the background environmental conditions. The clouds formed only where there was high humidity. So, in order to simulate the northern convective clouds that developed over the Murg valley, the moister air conditions at levels from 1.8 to $4.2 \mathrm{~km}$ amsl detected from the aircraft profile flight around this area at about 1420 UTC were used to replace the corresponding values of RH. The aerosol size distribution measured by the PCASP during a low-level boundary-layer run at 1340 UTC was used for the 'reference' run.

We also performed two other runs for this case. The reference run used the conventional Bigg immersionfreezing scheme (Bigg, 1953). The second run 'T1' used a new scheme of immersion freezing adopted from Diehl et al. (2006). The final run 'T2' used an initial aerosol loading of one fifth of the reference run, since the main, deep convective cell, studied by several authors in the COPS literature, formed in the southern part of the Black Forest in a region where fewer aerosols were measured by the instruments on the aircraft.

\subsubsection{Reference run}

The model results of the maximum values at any radial distance from the axis is shown as a function of altitude and time in Figure 5. The simulated cloud base and top are $z_{\mathrm{cb}} \approx 2.9 \mathrm{~km}$ amsl and $z_{\mathrm{ct}} \approx 6.5 \mathrm{~km}$ amsl (Figure 5(a)), respectively, which is in agreement with the IMK radar observations. The cloud-top temperature, $T_{\mathrm{ct}} \approx-12^{\circ} \mathrm{C}$, and the maximum updraught speed, $w_{\max }=12.8 \mathrm{~m} \mathrm{~s}^{-1}$ (Figure 5(e)) are also similar to the corresponding observed values. When the vertical velocity reached its peak, the 

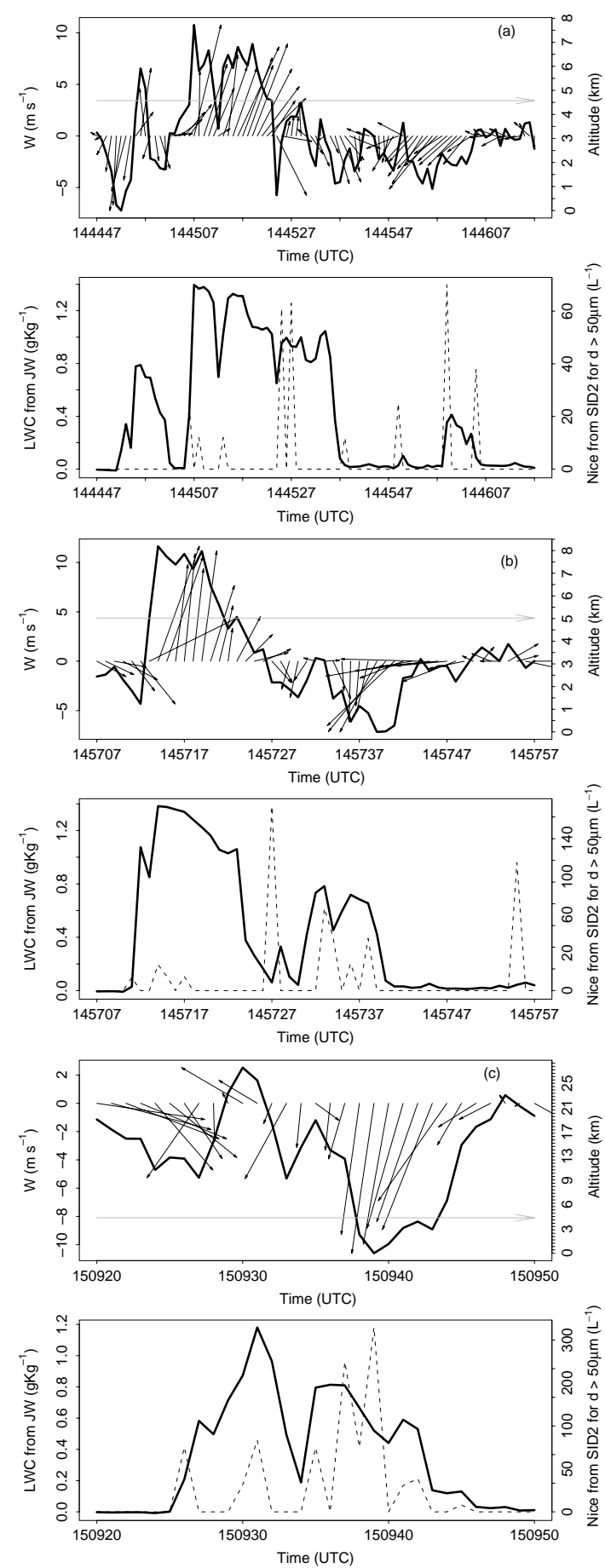

Figure 4. Observations on 15 July 2007 of vertical wind, LWC and concentration of ice particles larger than $50 \mu \mathrm{m}$ measured by SID-2 during penetrations: (a) at 1445 UTC, $\approx 4.6 \mathrm{~km}$ amsl, $T \approx-4{ }^{\circ} \mathrm{C}$, (b) at $1457 \mathrm{UTC}, \approx 5 \mathrm{~km}$ amsl, $T \approx-7^{\circ} \mathrm{C}$, and (c) at $1509 \mathrm{UTC}, \approx 5.3 \mathrm{~km}$ amsl, $T \approx-9^{\circ} \mathrm{C}$.

maximum concentration of drops is about $380 \mathrm{~cm}^{-3}$. The concentrations of graupel particles and raindrops are both low, and the maximum concentration of ice particles is only 4 litre $^{-1}$ (Figure 5(c), (d) and (b)). Notice that raindrops were produced before the graupel particles and hence by the warm rain process when the cloud was about $2.5 \mathrm{~km}$ deep. The reflectivity factor is shown for all three model runs in Figure 6. The maximum reflectivity in the reference run was $43.4 \mathrm{dBZ}$ (Figure 6(a)), which is approximately the same as that observed in the most intense of the northern clouds by the IMK radar. The rainfall with a reflectivity of
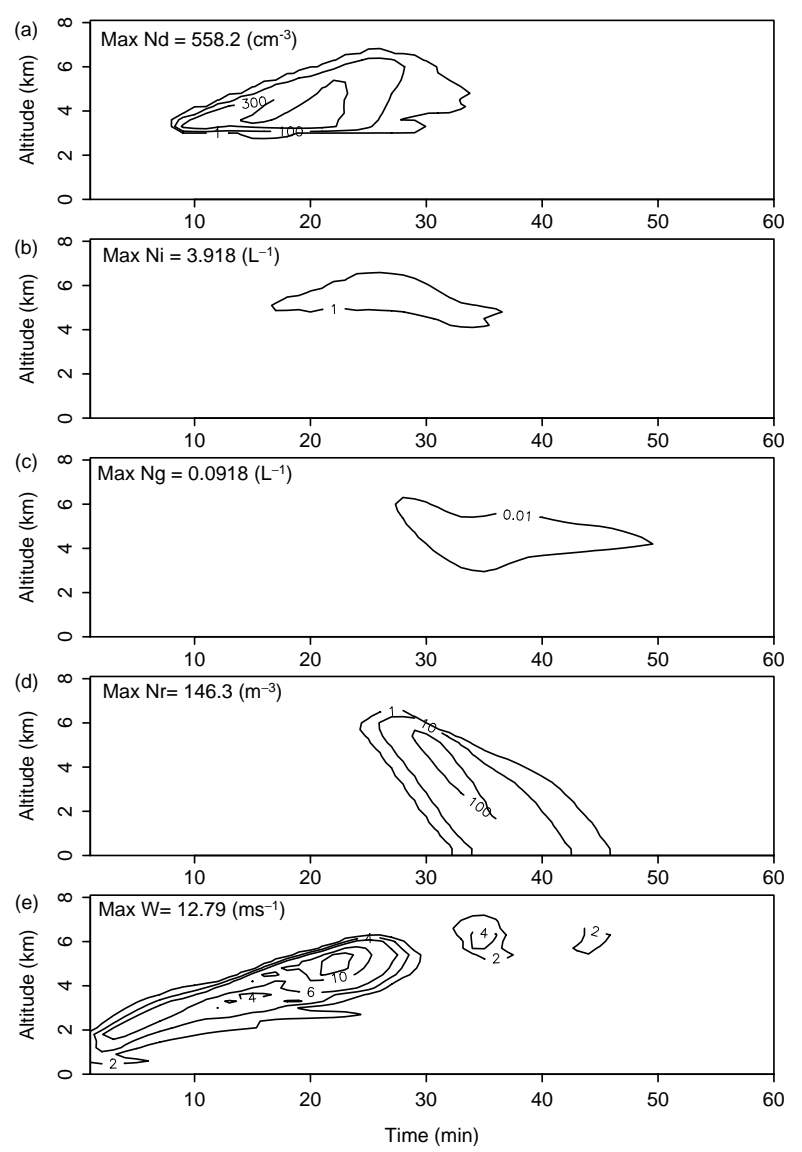

Figure 5. Reference run results for the 15 July cloud. The plots show the maximum values at any radial distance in the model of (a) the concentration of drops, (b) concentration of ice crystals, (c) concentration of graupel particles, (d) concentration of raindrops, and (e) vertical velocity.

at least $30 \mathrm{dBZ}$ occurred for about $10 \mathrm{~min}$. There are two factors responsible for the low concentration of ice crystals in the model results. The first is that the HM process did not operate because of the low concentration of graupel particles. The second is due to the low efficiency of ice nucleation at such high temperatures $\left(T>-12{ }^{\circ} \mathrm{C}\right)$ from the conventional immersion freezing scheme.

\subsubsection{Run T1: Enhanced IN}

Since a high concentration of organic material was possibly ingested into the cloud, we performed a model run with a new scheme for drop freezing introduced by Diehl and Wurzler (2004) and Diehl et al. (2006), in which a different type of ice nucleus was recognized by the different values of the constant $B_{h, i}$ that represents the ice nucleating efficiency in the immersion freezing mode of an insoluble particle per unit volume of liquid. The values were derived from laboratory experiments (Diehl et al., 2006, provide details). The value for leaf litter was used $\left(B_{h, i}=0.438 \mathrm{~cm}^{-3}\right)$. The results are shown in Figure 7. The concentration of ice crystals is much higher than in the reference run, with a maximum of 704 litre $^{-1}$, due to the enhanced ice nucleating ability of the biogenic aerosol in the new scheme. This is more consistent with the observations. Both the enhanced formation of ice particles or direct formation of graupel particles (depending on the droplet size) via the immersion mode, and the following formation of graupel by riming, deplete a significant fraction of the larger drops, leading 

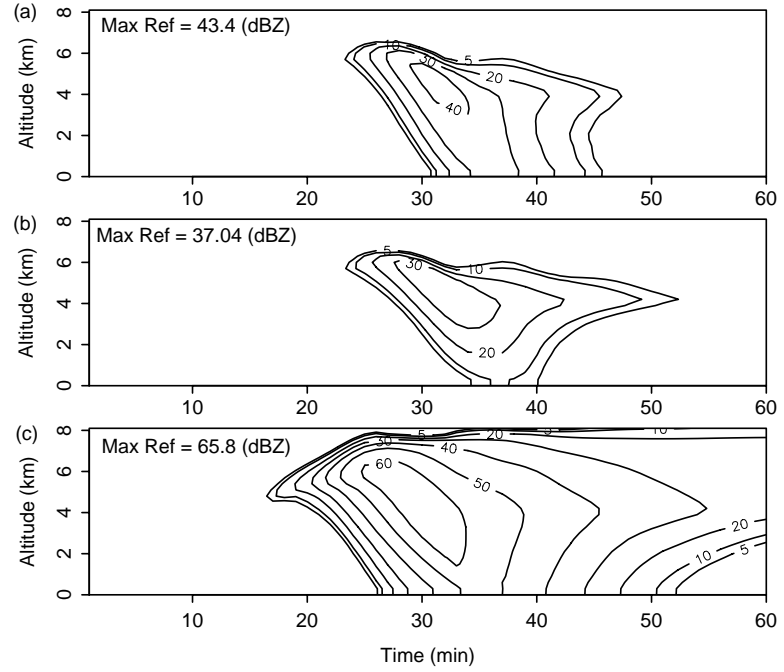

Figure 6. Evolution of maximum reflectivity in the model for (a) the reference run, (b) test run $\mathrm{T} 1$, and (c) test run $\mathrm{T} 2$.
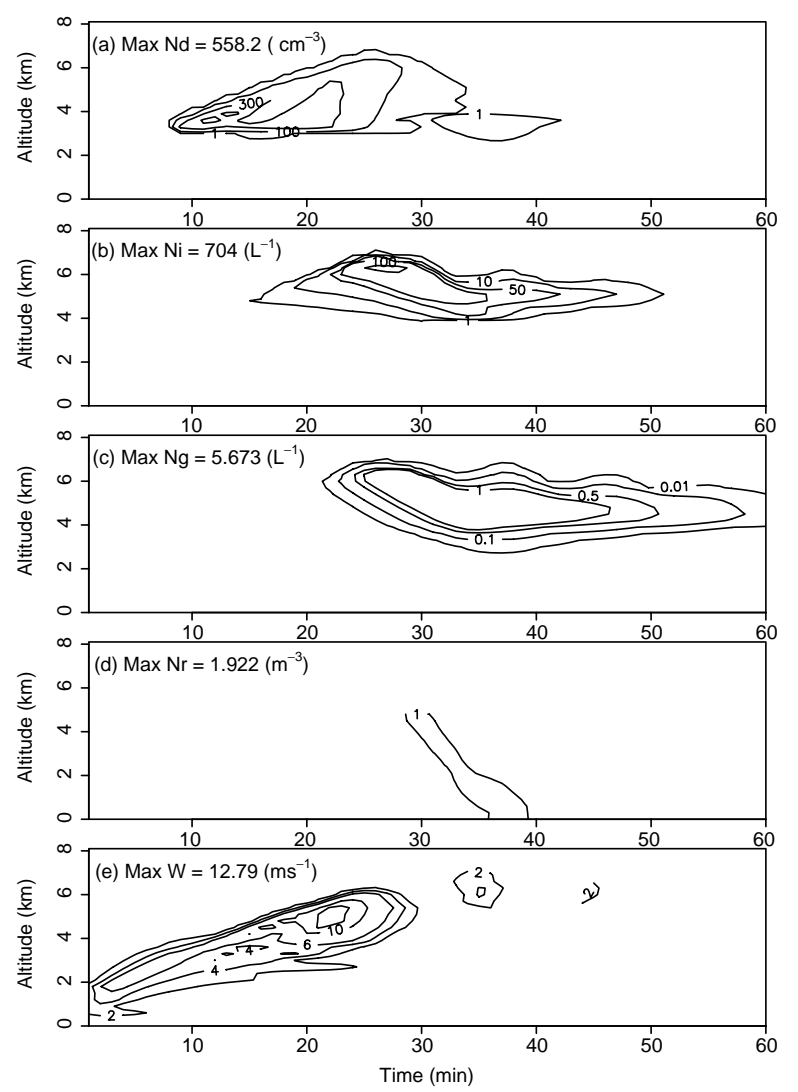

Figure 7. As Figure 5, but for the test run T1.

to the suppression of warm rain. The graupel particles produced in this run are not large enough to fall and tend to remain aloft as in the reference run (Figure $7(\mathrm{c})$ ). As a result, the precipitation reaching the ground is significantly reduced (Figure $7(\mathrm{~d})$ ) as is the reflectivity (Figure 6(b)). The maximum reflectivity is $37 \mathrm{dBZ}$, which is slightly less than in the reference run. This result is similar to the findings of Levin et al. (2005).

\subsubsection{Run T2: Low aerosols}

As mentioned above, two precipitating convective cells developed along the convergence lines on this day. The southern cell developed into a short-lived thunderstorm with heavy precipitation and hail (Kalthoff et al., 2009; Barthlott et al., 2011; Burton et al., 2011, pers. comm.). The IMK radar images show that the reflectivity of the southern cell was significantly stronger and the cloud top was much higher than that of the northern cell.

The high humidity values measured over the Murg valley were used in the simulation, so it is unlikely that the low cloud top attained by MAC3 (Figure 5) compared to the $12 \mathrm{~km}$ observed top in the southern cell was associated with humidity, as experienced in some larger-scale model runs (e.g. Burton et al., 2011, pers. comm.). However, the measurements from the $\mathrm{CO}, \mathrm{NO}_{\mathrm{x}}, \mathrm{CPC}$, PCASP on board the aircraft exhibited an interesting distribution in the concentration of pollution along the flight tracks (southsouthwest to northnortheast) in the two low-level runs over the mountains. The air in the north over the Murg valley is significantly more polluted than the air in the south over the Kinzig valley. For example, in the run at 1340 UTC, the concentration of aerosols measured by the CPC over the Murg valley was about five times that measured over the Kinzig valley. A similar enhancement of the number concentration was measured by the PCASP. The southern cloud formed and developed just at the east end of Kinzig valley, while the northern cell was located on the east side of the Murg valley.

In order to test the impact of aerosols on the cloud, we conducted a sensitivity test (T2) with an aerosol loading of one fifth that of the reference run, with everything else the same. The results from T2 are presented in Figure 8. The cloud top ascended to $z_{\mathrm{ct}} \approx 8 \mathrm{~km}$ amsl compared to $z_{\mathrm{ct}} \approx 6 \mathrm{~km}$ in the reference run and the cloud developed more vigorously. The concentration of ice crystals, graupel particles and raindrops increased significantly and the raindrops and graupel particles formed earlier than in the reference run. The reflectivity also increased to a maximum of $65 \mathrm{dBZ}$ and the maximum occurred about 6 min earlier (Figure 6). The features of run $\mathrm{T} 2$ are similar to the observations of the southern cell (Kalthoff et al., 2009), which suggests that the orography played a significant role in altering the microphysical behaviour of the clouds through the influence of venting of aerosols from the valleys. The discrepancy between the modelled and observed cloud top in test T2 suggests that there are other factors that influenced the altitude of the southern cloud, the investigation of which is beyond the scope of this study.

There are two factors which account for the more vigorous growth in the cleaner cloud with the higher top. The first is the cooling effect through evaporation, which occurred near the cloud boundary via entrainment and mixing of the cloud air with the ambient dry air and in the upper part of the cloud through the Bergeron mechanism. The cooling is much stronger in the polluted cloud because the average size of drops is much smaller, which promotes faster and stronger evaporation. As a result, the development of the polluted cloud is suppressed. This is consistent with the findings of Cui et al. (2006). The second factor is the water loading term. When the cloud develops to its mature stage, raindrops are produced which then fall out of the ascending parcels. Thus the loading term in the upper part of the 

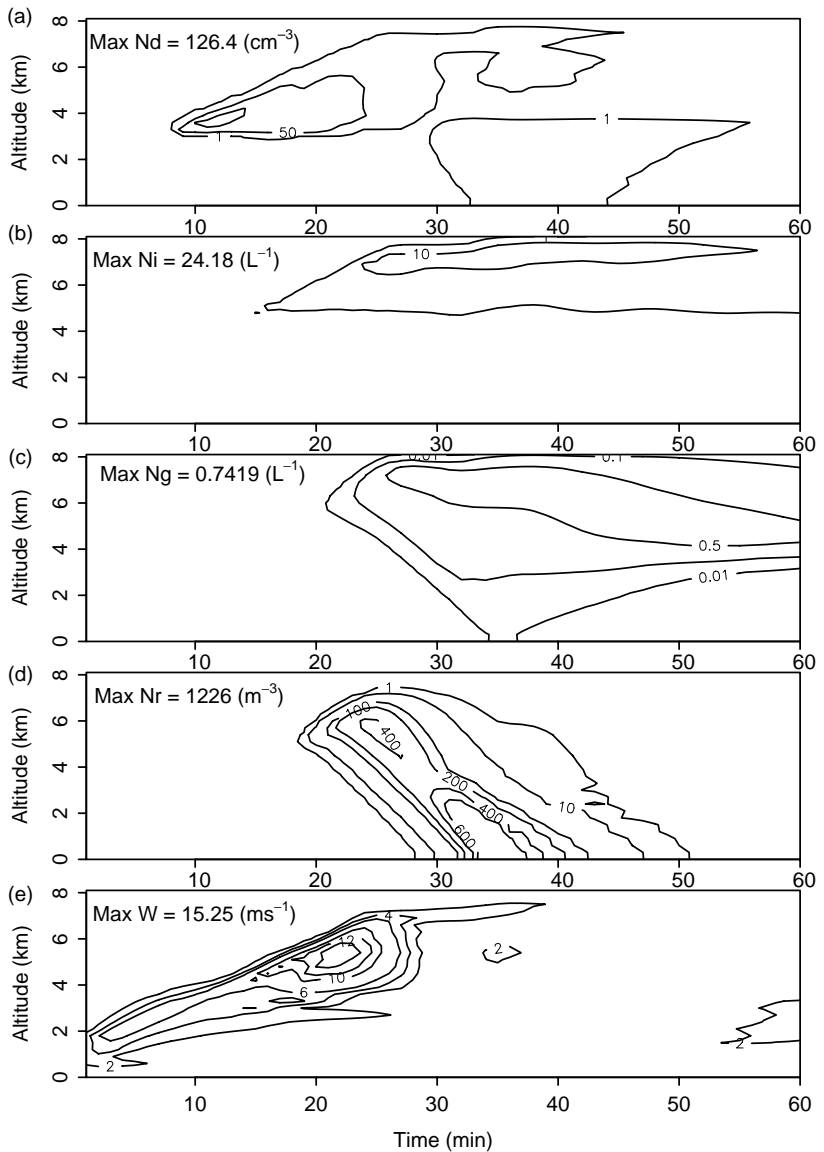

Figure 8. As Figure 5, but for the test run T2.

cloud is reduced. Many studies (e.g. Huang et al., 2008) have pointed out that raindrops are developed earlier and their concentration is higher in cleaner clouds (Figure 8(d)) than in polluted clouds (Figure 5(d)).

On the other hand, the sensitivity test shows that the pollution in the north has suppressed the cloud development rather than strenthening it, as suggested by Rosenfeld (2006). He proposed that pollution can invigorate warmbase deep convective clouds by sending more liquid droplets to supercooled levels where they can freeze and then release latent heat aloft (Rosenfeld, 2006). The model case discussed here had a colder base and warmer top than the clouds discussed by Rosenfeld. The cloud base and top had temperatures of about $8^{\circ} \mathrm{C}$ and $-12{ }^{\circ} \mathrm{C}$, respectively. The cooling effect caused by evaporation of small drops when mixing with the dry ambient air and co-existing with ice particles was apparently significant to dominate over the latent heat release by freezing of the droplets in the upper part of the cloud. This point has been presented in the work of Cui et al. (2006).

\section{Case 2: 11 July cloud}

\subsection{Observations}

On 11 July 2007, the COPS area was affected by a passing upper trough bringing cool west to northwest flow over the region. Convection developed, but was inhibited by a weak stable layer around $3 \mathrm{~km}$ amsl with an associated deep dry layer. The aircraft penetrated two convective clouds near their tops. The forward-facing camera showed that the first cloud was in a developing stage when penetrated at about $3.6 \mathrm{~km}$ amsl $\left(T \approx-7^{\circ} \mathrm{C}\right)$ from 1100 to 1114 UTC. The second cloud was in a mature to decaying stage when penetrated at about $3.3 \mathrm{~km}$ amsl from 1158 to 1205 UTC. The IMK radar images show that the tops of the radar echoes were about $3.0 \mathrm{~km}$ amsl. The clouds did not develop over the Black Forest mountains, but advected into the COPS region. The aircraft remained with the clouds for as long as possible. Only small concentrations of ice particles were measured in the first cloud. The maximum concentration of particles from the 2DC and 2DP instruments was only 15 and 0.2 litre $^{-1}$, respectively. The images from CPI are mostly of small droplets and only a few images of small columns and graupel were recorded by the 2DC.

In contrast, relatively high concentrations of ice particles were measured in the two penetrations made in the second cloud studied at altitudes of 3.4 and $3.1 \mathrm{~km}$ amsl $\left(T \approx-5^{\circ} \mathrm{C}\right)$. Figure 9 shows the results from the second penetration made at 1204 UTC. Many ice particles were recorded by the CPI. Figure 9(b) shows examples of the ice particle images, some of which are pristine columns while others are rimed. Even more images of ice particles, most of which are columns and graupel particles, were recorded by the $2 \mathrm{DC}$ instrument; examples are shown in Figure 9(c). The LWC is less than $1 \mathrm{~g} \mathrm{~m}^{-3}$ everywhere, but is even less on the downshear side of the cloud where there is a larger concentration of ice particles measured by the 2DC and 2DP instruments, similar to the 15 July case (Figure 4(b)). The maximum concentrations from 2DC and 2DP are about 400 and 50 litre $^{-1}$, respectively. The estimated concentration of ice particles with diameter $d>150 \mu \mathrm{m}$ from the combined 2DC and 2DP instruments was 80 litre $^{-1}$ (unfortunately, SID-2 did not work on 11 July), which far exceeds the estimation from the Meyers et al. (1992) formula derived from typical ice nuclei measurements at such a high temperature. As mentioned above, the IMK radar showed that the radar tops were about $3 \mathrm{~km}$ amsl. Of course, the history of the cloud before it reached the COPS region is unknown, as are the details of the $\mathrm{IN}$, but the observation of the co-existence of numerous ice particles, pristine columns, graupel particles and supercooled droplets within the temperature range of -3 to $-9{ }^{\circ} \mathrm{C}$ suggests that the HM process of splintering during riming may have been responsible for the relatively high concentration of ice particles. MAC3 model results are discussed below to help understand the early behaviour of the cloud and to test if the HM process did operate in these relatively shallow cumulus congestus clouds.

\subsection{MAC3 model results}

The initial environmental conditions used in the simulation were slightly adapted from Achern sounding at 1200 UTC, 11 July 2007. Figure 10 shows the spatial distribution of the concentrations of liquid drops and ice crystals and the wind vectors at $5 \mathrm{~min}$ intervals from 25 to $50 \mathrm{~min}$ of the model run. The simulated cloud developed to a maximum intensity at $t=35 \mathrm{~min}$. The maximum concentration of liquid drops at this time $\left(185 \mathrm{~cm}^{-3}\right)$ is consistent with the concentrations of $180 \mathrm{~cm}^{-3}$ observed by the CPI for all particles in a developing cloud with high LWC. Secondary ice particle production due to riming (HM process) became significant at $t=40 \mathrm{~min}$ when the simulated cloud was in a mature stage. The development of ice particles caused the 

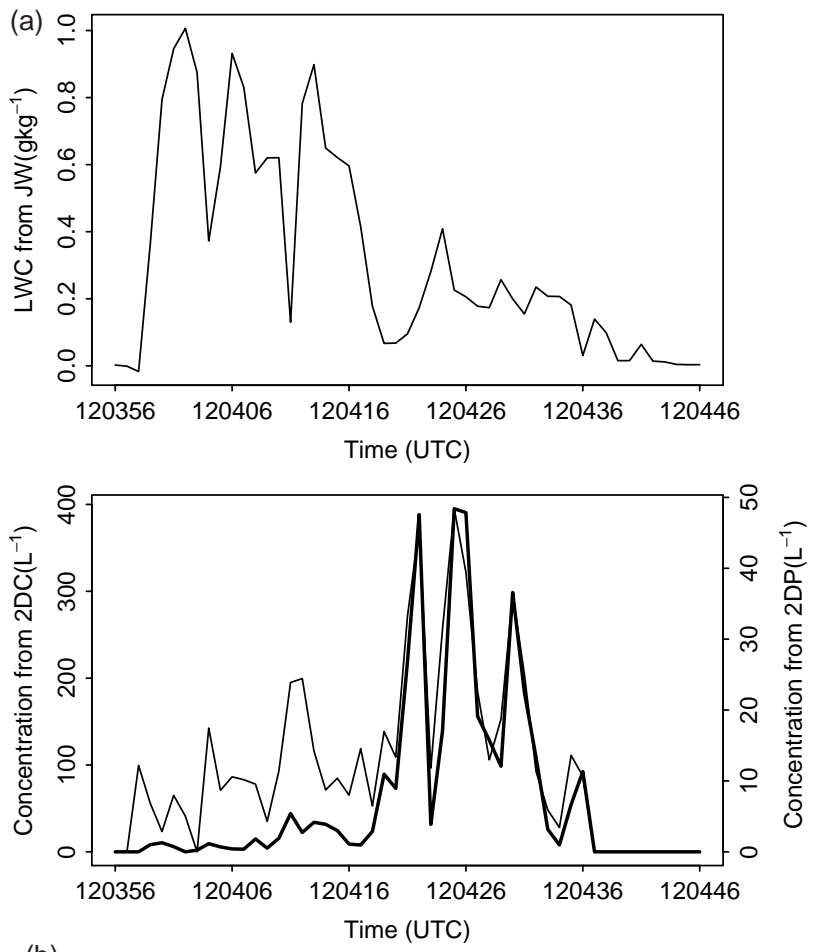

(b)

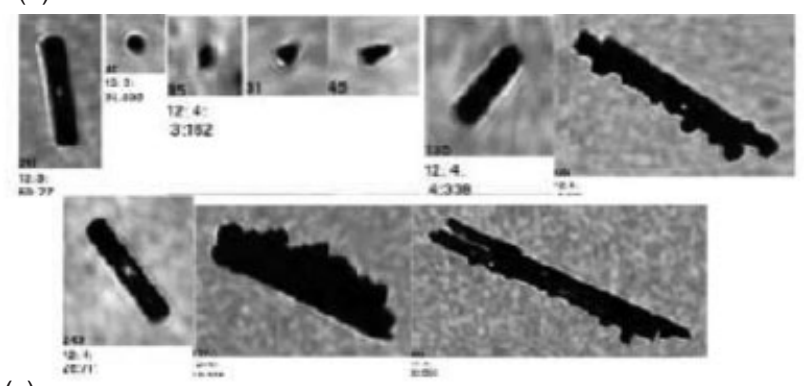

(c)

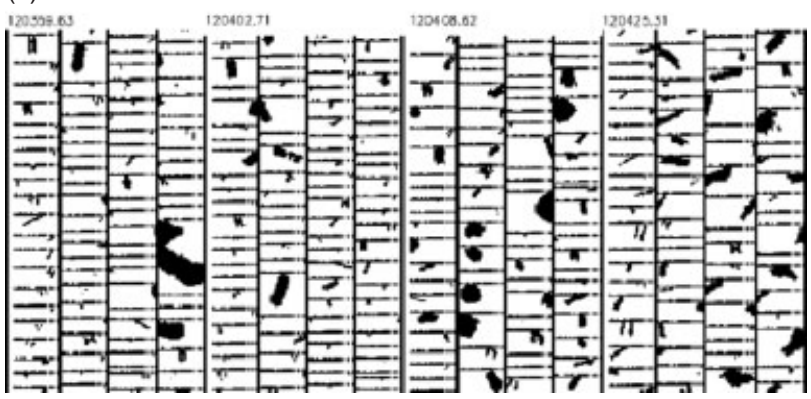

Figure 9. Observations from a penetration made in the downshear direction on 11 July 2007 at 1204 UTC. (a) LWC (upper) and concentration of particles (lower) measured by the 2DC and 2DP instruments. Examples of particle images from the CPI and 2DC instruments are shown in (b) and (c). For each CPI image box in (b), the particle size is shown on the lower left corner. The distance between the vertical lines in (c) represents $800 \mu \mathrm{m}$. The vertical wind is not shown because of icing problems in the instrument during the penetration.

cloud top to ascend to a higher altitude because of the extra release of latent heat. At $t=45 \mathrm{~min}$ (Figure 10(e)) the cloud is already in a decaying stage and the concentration of ice crystals has increased to a maximum of 66 litre $^{-1}$ at about $3 \mathrm{~km}$ amsl. The development of the high concentration of ice crystals is due to the HM process. The ice production rate by splintering reached a peak of 1 litre ${ }^{-1} s^{-1}$, while the rate by other nucleation processes only reached 0.02 litre $^{-1} s^{-1}$ (not shown). Because the concentration of graupel is critical to the effective operation of the HM process (Huang et al.,
2008), we compared the modelled graupel concentration with the concentration of particles larger than $1 \mathrm{~mm}$ from 2DP. The maximum values were 0.73 litre $^{-1}$ from the model versus 0.95 litre $^{-1}$ from 2DP. Therefore, the MAC3 results support the idea that the HM process is responsible for the high concentration of ice particles observed in the 11 July cloud.

\section{Conclusions}

An analysis has been presented of the microphysics of cumulus clouds observed on two days during the Convective and Orographically-induced Precipitation Study that was held over the Black Forest mountains in southwest Germany in the summer of 2007. The analysis suggests four points:

(i) High concentrations of ice particles were observed in clouds on 11 July. Conditions were conducive for the HM process and MAC3 model simulations confirmed that the high concentrations can be explained by the HM process.

(ii) High concentrations of relatively small ice particles (but with size larger than $50 \mu \mathrm{m}$ ) were observed with the SID-2 instrument in the northern cloud on 15 July which had a top no higher than $T \approx-12{ }^{\circ} \mathrm{C}$. The MAC3 model results suggested that drops were too small and there were insufficient graupel particles for the HM process to explain the observed concentrations. Biological nuclei, oxidised aerosol particles in the polluted air vented from the Murg valley into the cloud and desert dust are all possible candidates. A high mass fraction of oxidised organic material was measured by the ToF-AMS at supersite $\mathrm{H}$. Due to the nature of the site, the sub-micron aerosol composition, the presence of coarse mode material and the high biogenic activity, a different IN activity scheme for biogenic material (Diehl and Wurzler, 2004) was used in a model sensitivity study. The model results using this different scheme predicted the existence of a high concentration $\left(N_{\mathrm{i}} \approx 700\right.$ litre $\left.^{-1}\right)$ of small ice particles. The observations were uncertain as mentioned above, but there is some confidence in the 300 litre $^{-1}$ concentration of particles larger than $50 \mu \mathrm{m}$ measured by SID-2.

(iii) There was likely to be increased emissions of biogenic VOC oxidation products from the trees in the Black Forest on the hot and sunny days just before and including 15 July. The organic and inorganic material was found to be internally mixed suggesting that the organic material is secondary in nature and had condensed onto pre-existing aerosol particles, possibly as a result of the photo-oxidation of biogenic gas-phase material. This conclusion is supported by the observation of there being little black carbon, sulphate and nitrate, and also by the fact that the site is far from local pollution sources.

(iv) Venting of pollutants from valleys in the Black Forest mountains can have a significant influence on the microphysics and dynamics of the convective clouds in several ways. Firstly, it is possible that oxidised aerosol particles in polluted air could be more efficient ice nuclei and produce more ice 

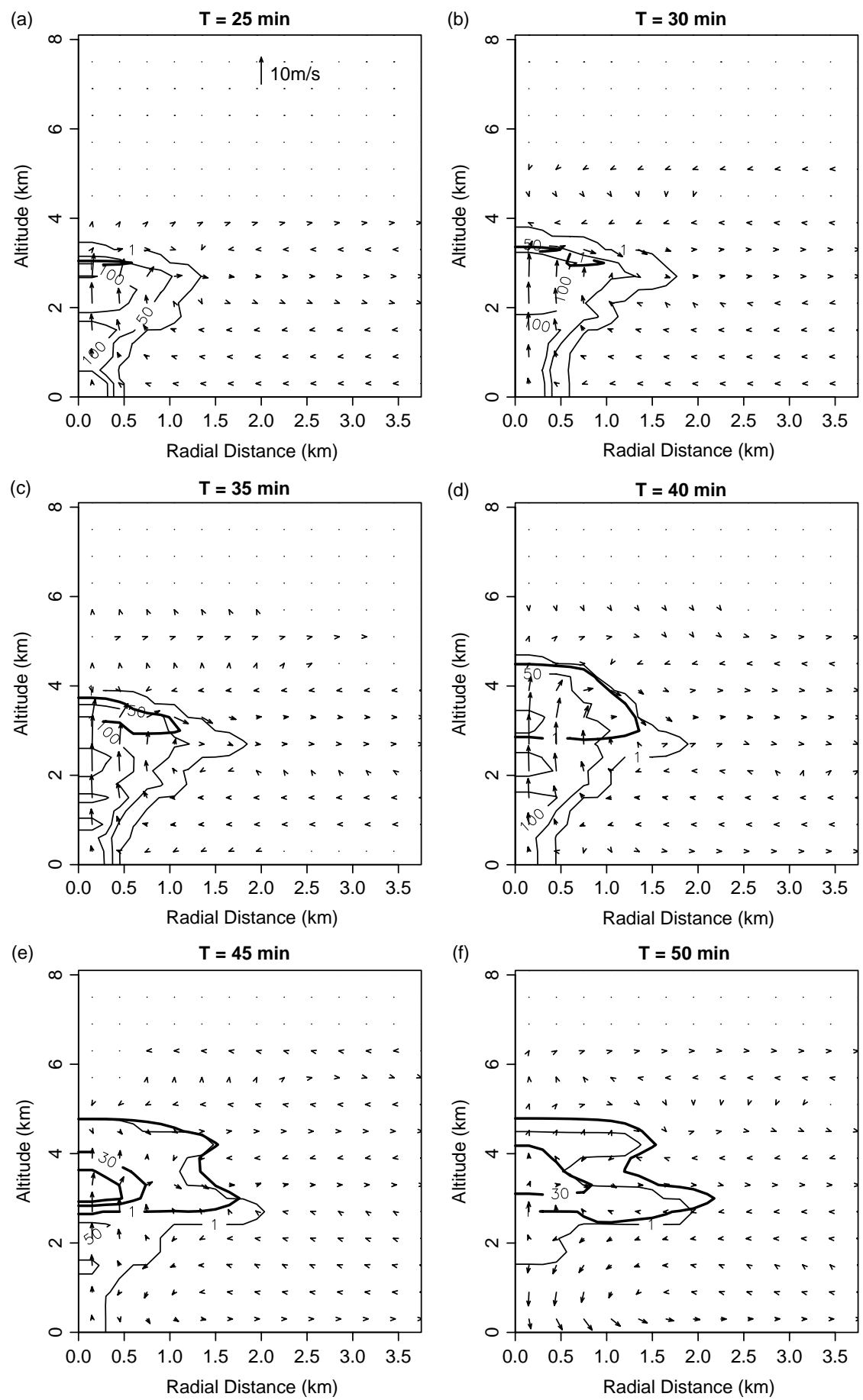

Figure 10. Spatial distributions of wind vectors and the concentration of drops and ice crystals and at times from 25 to 50 min. The thin lines are the concentration of liquid drops with contours at $1,50,100,150 \mathrm{~cm}^{-3}$. The bold lines are the concentration of ice crystals with contours at $1,30,50$ litre -1 The scale for the wind vectors is shown in (a).

than the parametrization scheme of Meyers et al. (1992), as suggested by Choularton et al. (2008). Secondly, the greater number of CCN particles results in there being smaller drops, which can more readily evaporate at cloud top causing a lower cloud top. Also more condensate is carried along, weighing down the ascending cloud. So the model predicts that more polluted clouds are shallower and produce less rain.

The secondary production of ice by splintering during riming - the HM process -is known to be important in many convective clouds, now most likely including the 11 July clouds. However, as mentioned above, conditions do not appear to have been favourable for this process to be active in the northern 15 July 2007 cloud, mainly because cloud base was high and there was a large concentration of relatively small cloud particles and few graupel particles. Blyth and Latham (1993) observed a similar case over the mountains of central New Mexico when moisture was just returning to the area and cloud bases were high as a result. The reference MAC3 model run produced low concentrations of ice particles.

Several large-scale model studies have been performed for the 15 July case by Barthlott et al. $(2009,2011)$ and (Burton et al., 2011, pers. comm.). Also, Kottmeier et al. (2008) 
used COPS data to examine the processes responsible for the initiation of the cloud. The results of the current study provide a different perspective, specifically of the role of the aerosols that are transported by the flows in the complex terrain, on the microphysical and dynamical properties of the cloud. The transport of pollution is well-known in complex terrain. For example, Fiedler et al. (2000) used $\mathrm{SF}_{6}$ as a tracer to show that winds transport pollutant-loaded air masses from Freiburg up to the summits of the Black Forest during the day. Thus the properties of the convection that was initiated by orographically influenced flows may also be modified by differences in aerosol loadings that are also generated within the flows.

\section{Acknowledgements}

We would like to thank the pilots and staff of the FAAM BAE aircraft for making the flights, and instrument scientists of the Facility for Ground-based Atmospheric Measurements (FGAM) for running instruments on the aircraft and on the ground. We are grateful to Prof. Volker Wulfmeyer and Dr Andreas Behrendt for leading COPS, and to Dr Ulrich Corsmeier for the tireless work in coordinating the aircraft missions and in securing the 'boxes' over the Black Forest for aircraft operations, and to all the many scientists that were involved in the field campaign. We are grateful to Drs Jim McQuaid and Zhiqiang Cui for discussions that helped with arguments presented in the paper, and to Dr Lindsay Bennett for assistance with the diagrams. The COPS project was supported by the Natural Environment Research Council (NERC), NE/E018483/1. FAAM is supported by NERC and the Met Office, and FGAM by NERC.

\section{References}

Aoshima F, Behrendt A, Bauer H-S, Wulfmeyer V. 2008. Statistics of convection initiation by use of Meteosat rapid scan data during the Convection and Orographically-induced Precipitation Study (COPS). Meteorol. Z. 17: 921-930.

Barthlott C, Schipper J, Kalthoff N, Adler B, Kottmeier C, Blyth AM, Mobbs SD. 2009. Model representation of boundarylayer convergence triggering deep convection over complex terrain: A case study from COPS. 2009. Atmos. Res. 95: 172-185. DOI: 10.1016/j.atmosres.2009.09.010.

Barthlott C, Burton R, Kirshbaum D, Hanley K, Richard E, Chaboureau JP, Trentmann J, Kern B, Bauer H-S, Schwitalla T, Keil C, Seity Y Gadian A, Blyth A, Mobbs S, Flamant C, Handwerker J. 2011 Initiation of deep convection at marginal instability in anensemble of mesoscale models: a case-study from COPS. Q. J. R. Meteorol. Soc. 137(S1): 118-136, DOI: 10.1002/qj.707.

Behrendt A, Pal S, Aoshima F, Bender M, Blyth A, Corsmeier U, Cuesta J Dick G, Dorninger M, Flamant C, Di Girolamo P, Gorgas T, Huang Y, Kalthoff N, Khodayar S, Mannstein H, Träumner K, Wieser A, Wulfmeyer V. 2011. Observation of convection initiation processes with a suite of state-of-the-art research instruments during COPS IOP 8b. Q. J. R. Meteorol. Soc. 137(S1): 81-100, DOI: 10.1002/qj.710.

Bigg E. 1953. The formation of atmospheric ice crystals by the freezing of droplets. Q. J. R. Meteorol. Soc. 79: 510-519.

Blyth AM, Latham J. 1993. Development of ice and precipitation in New Mexican summertime cumulus clouds. Q. J. R. Meteorol. Soc. 119: 91- 120 .

Blyth AM, Lasher-Trapp SG, Cooper WA. 2005. A study of thermals in cumulus clouds. Q. J. R. Meteorol. Soc. 131: 1171-1190.

Bower K, Moss S, Johnson D, Choularton T, Latham J, Brown P, Blyth AM, Cardwell J. 1996. A parametrization of the ice water content observed in frontal and convective clouds. Q. J. R. Meteorol. Soc. 122: 1815-1844.

Choularton T, Bower K, Weingartner E, Crawford I, Coe H, Gallagher M, Flynn M, Crosier J, Connolly P, Targino A, Alfarra M, Baltensperger U, Sjogren S, Verheggen B, Cozie J, Gysel M. 2008. The influence of small aerosol particles on the properties of water and ice clouds. Faraday Discuss. 137: 205-222.

Connolly PJ, Flynn MJ, Ulanowski Z, Ibbottson T, Gallagher MW, Choularton TW. 2007. Calibration of the cloud particle imager probes using calibration beads and ice crystal analogs: The depth-of-field. J. Atmos. Oceanic Technol. 24: 1860-1879.

Cotton R, Osborne S, Ulanowski Z, Hirst E, Kaye PH, Greenaway RS. 2010. The ability of the Small Ice Detector (SID-2) to characterize cloud particle and aerosol morphologies obtained during flights of the FAAM BAE-146 research aircraft. J. Atmos. Oceanic Technol. 27: 290-303.

Cui Z, Carslaw K. 2006. Enhanced vertical transport efficiency of aerosol in convective clouds due to increases in tropospheric aerosol abundance. J. Geophys. Res. 111: D15. DOI: 10.1029/2005JD00678.

Cui Z, Carslaw K, Yin Y, Davies S. 2006. A numerical study of aerosol effects on the dynamics and microphysics of a deep convective cloud in a continental environment. J. Geophys. Res. 111: D5. DOI: 10.1029/2005JD00598.

Diehl K, Wurzler S. 2004. Heterogeneous drop freezing in the immersion mode: Model calculations considering soluble and insoluble particles in the drops. J. Atmos. Sci. 61: 2063-2072.

Diehl K, Simmel M, Wurzler S. 2006. Numerical sensitivity studies on the impact of aerosol properties and drop freezing modes on the glaciations, microphysics, and dynamics of clouds. J. Geophys. Res. 111: D07202. DOI: 10.1029/2005JD00588.

Drewnick F, Hings SS, DeCarlo PF, Jayne JT, Gonin M, Fuhrer K, Weimer S, Jimenez JL, Demeriian KL, Borrmann S, Worsnop DR. 2005. A new Time-of-Flight Aerosol Mass Spectrometer (ToF-AMS): Instrument description and first field deployment. Aerosol Sci. Tech. 39: 637-658.

Fiedler F, Bischoff-Gauss I, Kalthoff N, Adrian G. 2000. Modeling of transport and dispersion of SF6 in the Freiburg-Schauinsland area. J. Geophys. Res. 105: D1. 1599-1610.

Field PR, Möhler O, Connolly P, Krämer M, Cotton R, Heymsfield AJ, Saathoff H, Schnaiter M. 2006. Some ice nucleation characteristics of Asian and Saharan desert dust. Atmos. Chem. Phys. 6: 2991-3006.

Gilmore JS. 2002. Design and performance characteristics of three continuous-flow condensation particle counters: A summary. Atmos. Res. 62: 267-294.

Golding BW, Clark P, May B. 2005. Boscastle flood: Meteorological analysis of the conditions leading to flooding on 16 August 2004. Weather 60: 230-235.

Gras J. 1995. CN, CCN and particle size in Southern Ocean air at Cape Grim. Atmos. Res. 35: 233-251.

Hallett J, Mossop S. 1974. Production of secondary ice crystals during the riming process. Nature 249: 26-28.

Harris-Hobbs R, Cooper W. 1987. Field evidence supporting quantitative predictions of secondary ice production rate. J. Atmos. Sci. 44: 1071-1082.

Hobbs P, Rangno A. 1985. Ice particle concentrations in clouds. J. Atmos. Sci. 42: 2523-2549.

Hogan R, Field P, Illingworth A, Cotton R, Choularton T. 2002. Properties of embedded convection in warm-frontal mixed-phase cloud from aircraft and polarimetric radar. Q. J. R. Meteorol. Soc. 128: $451-476$.

Huang Y, Blyth AM, Brown P, Choularton T, Connolly P, Gadian A, Jones H, Latham J, Cui Z, Carslaw K. 2008. The development of ice in a cumulus cloud over southwest England. New J. Phys. 10: DOI: 10.1088/1367-2630/10/1/10502.

Irwin M, Good N, Crosier J, Choularton TW, McFiggans G. 2010. Reconciliation of measurements of hygroscopic growth and critical supersaturation of aerosol particles in southwest Germany. Atmos. Chem. Phys. Discuss. 10: 17073-17111.

Jensen JB, Granek H. 2002. Optoelectronic simulation of the PMS 260X Optical Array Probe and application to drizzle in a marine stratocumulus, J. Atmos. Oceanic Technol. 19: 376-389.

Kalthoff N, Adler B, Barthlott C, Corsmeier U, Mobbs S, Crewell S, Träumner K, Kottmeier C, Wieser A, Smith V, Di Girolamo P. 2009. The impact of convergence zones on the initiation of deep convection: A case study from COPS. Atmos. Res. 93: 680-694, DOI: 10.1016/j.atmosres.2009.02.01.

Kin Y, Boatman J. 1990. The effects that the optical properties of particles have on atmospheric aerosol measurements with optical particle spectrometers. J. Aerosol Sci. 21: S551-S554.

Knollenberg RG. 1970. The optical array: An alternative to extinction and scattering for particle size measurement. J. Appl. Meteorol. 9: 86-103. 
Korolev AV. 2007. Reconstruction of the sizes of spherical particles from their shadow images. Part I: Theoretical considerations. J. Atmos. Oceanic Technol. 24: 376-389.

Kottmeier C, Kalthoff N, Barthlott C, Corsmeier U, Van Baelen J, Behrendt A, Behrendt R, Blyth A, Coulter R, Crewell S, Di Girolamo P, Dorninger M, Flamant C, Foken T, Hagen M, Hauck C, Höller H, Konow H, Kunz M, Mahlke H, Mobbs SD, Richard E, Steinacker R, Weckwerth TM, Wieser A, Wulfmeyer V. 2008. Mechanisms initiating deep convection over complex terrain during COPS. Meteorol. Z. 17: 931-948.

Lawson PR, Baker BA, Schmitt CG, Jensen TL. 2001. An overview of microphysical properties of Arctic clouds observed in May and July 1998 during FIRE ACE. J. Geophys. Res. Atmos. 106(D14): 14989-15014.

Lenschow DH, Spyers-Duran P. 1987. Measurement techniques: Air motion sensing. Research Aviation Facility Bulletin 23: NCAR: Boulder.

Levin Z, Cotton W. 2009. Aerosol pollution impact on precipitation: A scientific review. Springer Netherlands.

Levin Z, Teller A, Ganor E, Yin Y. 2005. On the interactions of mineral dust, sea-salt particles, and clouds: A measurement and modeling study from the Mediterranean Israeli Dust Experiment campaign. J. Geophys. Res. 110: D20202, DOI: 10.1029/2005JD005810.

Mentel TF, Wildt J, Kiendler-Scharr A, Kleist E, Tillmann R, Dal Maso M, Fisseha R, Hohaus T, Spahn H, Uerlings R, Wegener R, Griffiths PT, Dinar E, Rudich Y, Wahner A. 2009. Photochemical production of aerosols from real plant emissions. Atmos. Chem. Phys. 9: 4387-4406.

Meyers M, DeMott P, Cotton W. 1992. New primary ice-nucleation parameterizations in an explicit cloud model. J. Appl. Meteorol. 31: $708-721$.

Möhler O, Büttner S, Linke C, Schnaiter M, Saathoff H, Stetzer O, Wagner R, Krämer M, Mangold A, Ebert V, Schurath U. 2005. Effect of sulfuric acid coating on heterogeneous ice nucleation by soot aerosol particles. J. Geophys. Res. 110: D11210.

Möhler O, Field P, Connolly P, Saathoff H, Schnaiter M, Wagner R, Cotton R, Krämer M, Mangold A, Heymsfield A. 2006. Efficiency of the deposition mode of ice nucleation on mineral dust particles. Atmos. Chem. Phys. 6: 1539-1577.

Mossop SC. 1978. The influence of drop size distribution on the production of secondary ice particles during graupel growth. Q. J. R. Meteorol. Soc. 104: 323-330.

Mossop SC. 1985. Microphysical properties of supercooled cumulus clouds in which an ice particle multiplication process operated. Q. J. R. Meteorol. Soc. 111: 183-198.

Mossop SC, Hallett J. 1974. Ice crystal concentration in cumulus clouds: Influence of the drop spectrum. Science 186: 632-634.

Mossop SC, Cottis R, Bartlett B. 1972. Ice crystal concentrations in cumulus and stratocumulus clouds. Q. J. R. Meteorol. Soc. 98: $105-123$.

Pratt K, DeMott P, French J, Wang Z, Westphal D, Heymsfield A, Twohy C, Prenni A, Prather K. 2009. In situ detection of biological particles in cloud ice crystals. Nature Geosci. 2: 398-401.

Reisin T, Levin Z, Tzivion S. 1996. Rain production in convective clouds as simulated in an axisymmetric model with detailed microphysics. Part I: Description of the model. J. Atmos. Sci. 53: 497-520.
Richard E, Chaboureau J-P, Flamant C, Champollion C, Hagen M, Schmidt K, Kiemle C, Corsmeier U, Barthlott C, Di Girolamo P. 2011. Forecasting summer convection over the Black Forest: a casestudy from the Convective and Orographically-induced Precipitation Study (COPS) experiment. Q. J. R. Meteorol. Soc. 137(S1): 101-117, DOI: $10.1002 /$ qj.710.

Rosenfeld D. 2006. Aerosol-cloud interactions control of Earth radiation and latent heat release budgets. Space Sci. Rev. 125: 149-157. DOI: 10.1007/s11214-006-9053-6.

Saunders C, Hosseini A. 2001. A laboratory study of the effect of velocity on Hallett-Mossop ice crystal multiplication. Atmos. Res. 59: 3-14.

Schroth AC, Chandra MS, Mesichne PF. 1988. A C-Band coherent polarimetric radar for propagation andcloud physics research. J. Atmos. Oceanic Technol. 5: 803-822.

Soulage F. 1966. Counting and electron microscope study of European ice nuclei. J. Rech. Atmos. 3: 219-229.

Strapp JW, Leaitch WR, Liu PSK. 1992. Hydrated and dried aerosolsize distribution measurements from the particle measuring systems FSSP-300 probe and the deiced PSASP-100X probe. J. Atmos. Oceanic Technol. 9: 548-555.

Szyrmer W, Zawadzki I. 1997. Biogenic and anthropogenic sources of ice-forming nuclei: A review. Bull. Am. Meteorol. Soc. 78: 209-228.

Wulfmeyer V, Behrendt A, Bauer H-S, Kottmeier C, Corsmeier U, Blyth A, Craig G, Schumann U, Hagen M, Crewell S, Di Girolamo P, Flamant C, Miller M, Montani A, Mobbs S, Richard E, Rotach MW, Arpagaus M, Russchenberg H, Schlüssel P, König M, Gärtner V, Steinacker R, Dorninger M, Turner DD, Weckwerth T, Hense A, Simmer C. 2008. The Convective and Orographically induced Precipitation Study: A research and development project of the World Weather Research Program for improving quantitative precipitation forecasting in low-mountain regions. Bull. Am. Meteorol. Soc. 89: 1477-1486.

Wulfmeyer V, Behrendt A, Kottmeier C, Corsmeier U, Barthlott C, Craig GC, Hagen M, Althausen D, Aoshima F, Arpagaus M, Bauer HS, Bennett L, Blyth A, Brandau C, Champollion C, Crewell S, Dick G, Di Girolamo P, Dorninger M, Dufournet Y, Eigenmann R, Engelmann R, Flamant C, Foken T, Gorgas T, Grzeschik M, Handwerker J, Hauck C, Höller H, Junkermann W, Kalthoff N, Kiemle C, Klink S, König M, Krauss L, Long CN, Madonna F, Mobbs S, Neininger B, Pal S, Peters G, Pigeon G, Richard E, Rotach MW, Russchenberg H, Schwitalla T, Smith V, Steinacker R, Trentmann J, Turner DD, van Baelen J, Vogt S, Volker H, Weckwerth T, Wernli H, Wieser A, Wirth M. 2011. The Convective and Orographicallyinduced Precipitation Study (COPS): the scientific strategy, the field phase, and research highlights. Q. J. R. Meteorol. Soc. 137(S1): 3-30, DOI: $10.1002 / q j .752$.

Yin Y, Levin Z, Reisin T, Tzivion S. 2000. The effects of giant cloud condensation nuclei on the development of precipitationin convective clouds: A numerical study. Atmos. Res. 53: 91-116.

Yin Y, Carslaw K, Feingold G. 2005. Vertical transport and processing of aerosols in a mixed-phase convective cloud and the feedback on cloud development. Q. J. R. Meteorol. Soc. 131: 221-245. 